\title{
Methodology of reconstruction of the Old-Polish road network as exemplified by the historic Lublin Voivodship
}

\begin{abstract}
The aim of the author is to present the methodology of reconstruction of the Old-Polish transport network as exemplified by the historic Lublin Voivodship. The author discusses the research method and procedure of reconstructing the road routes and locations of transport facilities on the basis of text sources and old maps of varied content and geometric accuracy. The adopted methodology uses GIS tools to analyse and verify data from both cartographic and descriptive sources. The analysis is based on the retrogressive approach, as most of the cartographically reliable sources come from the early 19th century.

The presented research procedure consists of three stages: preparation and processing of source material, registration of source information, and finally, its harmonization. The research procedure consists of two main steps: 1) identification (initial identification of the object and verification of its existence); 2) geometrisation (determination of geometrical parameters of the object, followed by their verification, and confirmation of the object's course or location in the spatial database).
\end{abstract}

Keywords: transport network, historical geography, historical GIS, retrogressive method, Lublin Voivodship

\section{Introduction}

The task of recreating the layout of a road network is an interdisciplinary endeavour that requires employment of tools and skills from several scientific fields, such as cartography, geography, history, archaeology, toponomastics, and transport theory (E. Siemianowska 2012; J. Tyszkiewicz 2014). The interdisciplinary approach is needed because the issue in question is very complex. The transport network consists of two main elements:

1) roads:

- land routes, understood mostly as main (public) roads;

- waterways, understood as legally defined navigable rivers;

2) transport facilities understood as permanent elements of the road infrastructure without which movement of people and vehicles would not be possible (W. Ratajczak 1999; J. Tyszkiewicz 2014).
Identification of the transport network would not be possible without access to available and varied historical and geographical sources, just as its reconstruction would not come to pass without the right methodology.

The here described methodology makes it possible to recreate the layout of the transport network from the second half of the 18th century. In the author's opinion, this is the only period with rich enough source materials to allow for a relatively reliable and accurate analysis of the transport network of the Old Poland era. The partitions of Polish territory introduced great changes to the transport network of the country. Over the years, the partitioners introduced numerous road legislations regulating the process of construction and maintaining roads on the central level, which led to a systematic expansion of land and waterway connections, changing the Old-Polish transport system (R. Kowalczyk 2004). 


\section{Sources and research methods}

There is a clear interdependence between the source base (especially its cartographic part) and the methodology of reconstruction of the transport network layout. In Poland, the discussion on the research potential of sources for the transport network reconstruction has been on-going for nearly a hundred years. Karol Buczek (1930) claimed that even the most perfect text can never match the content value of a cartographic work. For obvious reasons, this opinion requires some clarification. In the absence of reliable old maps, it might seem more appropriate to take a different approach. For instance, A. Janeczek (2013, p. 24) claimed that "the sources relevant for the period in question should be the basis for any reconstruction". At the same time, he indicated that the written and archaeological sources should be given the priority and positioned historic maps as auxiliary sources used retrospectively to reconstruct road geometry for the Old Poland era. Some researchers remain doubtful about such treatment of cartographic materials created after the analysed period, asking whether "it does not undermine the very concept of the retrogressive method" (B. Szady 2018, p. 137).

Despite assigning the highest value to written sources, A. Janeczek (2013, p. 24) emphasised also that "the map must be the basis of analyses, a tool which allows to place individual references within space, an auxiliary means for resolving doubts [...] and a basis for merging dispersed, fragmentary [...] information into one coherent image." Nevertheless, it cannot be used as an independent source, and the image reproduced on its basis should be verified with different kind of sources.

No single type of sources should be favoured in the context of reconstruction of the transport network, as no source data should be treated as certain if it was not first verified by crosschecking information on the basis of different types of sources. The rule applies also to information concerning localization of roads and transport facilities on maps.

The primary source covered by the query was the 1:225,000 Special Map of the Lublin Voivodship of Charles Perthées (Polish: Mappa szczegulna województwa lubelskiego) drawn in 1786 (hereinafter: Special Map of the Lublin Voivodship of C. Perthées).
The following maps were used as reference and comparative materials:

- the 1:28,800 hand-drawn Map of West Galicia of Colonel Anton Mayer von Heldensfeld drawn in 1801-1804 (hereinafter: Heldensfeld's Map of Western Galicia);

- Topographic Map of the Polish Kingdom (Polish: Topograficzna Karta Królestwa Polskiego - TKKP) (hereinafter referred to as the Quartermaster's Map) of 1822-1843 at the scale of 1:126,000;

- the 1:100,000 Tactical Map of the Military Geographical Institute from 1930-1936 (hereinafter: MGI Tactical Map).

Modern digital data - Digital Terrain Models (DTM) derived from the ALS (Airborne Laser Scanning) data - were treated as cartographic sources. This type of data is commonly used in archaeology as a non-invasive method of researching cultural monuments, as it allow to identify elements of the transport network, even in wooded areas (A. Affek 2014; Ł. Banaszek 2014; M. Szilágyi 2014).

Written sources were divided into descriptive and statistical ones, with the two groups represented both by hand-written and printed materials. The varied source basis results from the need to search for information scattered among materials which differ in terms of their provenance, typology and age. The most important source used for recreation of the main road network was the Geographical and Statistical Description of Parishes of the Kingdom of Poland in 1796 (Polish: Geograficzno-statystyczne opisanie parafiów Królestwa Polskiego w roku 1796), drawn by C. Perthées, a geographer of King Stanisław II Augustus ${ }^{1}$ (hereinafter: Geographical and Statistical Description of Parishes...). Document sources, such as Volumina Legum (hereinafter: $V L$ ) and the Inventory of Constitutions of the Crown of the Kingdom of Poland and the Grand Duchy of Lithuania (Polish: Inwentarz Konstytucyy Koronnych y W. X. Lit.), which contained records of all royal privileges and sejm constitutions, also constituted important source materials. The course of some of the routes was identified on the basis of the Bridge and Causeway Tariffs of the Lublin Voivodship of 1767 (Polish: Taryfy mostowego i grobelnego województwa lubelskiego z 1767)

\footnotetext{
1 The manuscript was found at the V. Vernadsky National Library of Ukraine in Kiev (reference no. I 5975).
} 
(hereinafter: Bridge and Causeway Tariff) (Z. Góralski 1956). The press of the period, foremost issues of Dziennik Handlowy² [Trade Journal], was used to describe postal connections of the analysed area (M. Zawadzki 2018). An analysis of statistical sources, whose extracts can be found in the so-called Buczek Catalogue, was used as a supplementary material ${ }^{3}$.

\section{Description of the research method}

Any study of a cultural landscape, which includes roads, requires the use of natural, humanistic, social and technical sciences (D. Denecke 1979; K. Nieścioruk 2004; U. Myga-Piątek 2005; B. Szady 2008; J Plit 2014; J. Tyszkiewicz 2014), as the research subject is multi-faceted and thus necessitates employment of an interdisciplinary approach. This is also true in the case of contemporary historical geography and its methods (B. Szady 2012a, 2018).

The retrogressive method, which allows to determine earlier facts on the basis of later facts, is the basic research method used to reconstruct the representation of the transport network. Its use is motivated by the lack of cartometric maps from the Old Poland period showing the layout of roads in the analysed area. What is more, if we take into account the assumption that until the early 19th century the routes marked by roads had the tendency to remain fairly stable (H. Rutkowski 1993), the use of retrogression becomes even more justified. The method of chronological comparisons has been developed in Poland for almost a hundred years (W. Semkowicz 1925; S. Arnold 1929; T. Wąsowiczówna 1953, 1959, 1964). The main disadvantages of the method are related to the doubts concerning correctness of the results obtained on the basis of materials which are chronologically distant from one another e.g. when data from the beginning of the 19 th century is used to reconstruct the road system from the second half of the 16th century.

\footnotetext{
2 The journal's full title: "Dziennik Handlowy zawierający w sobie wszystkie okoliczności, czyli ogniwa całego łańcucha handlu polskiego. Zaczęty w Warszawie roku 1786" [The Trade Journal including all the circumstances, that is all the elements of the chain of the Polish trade. Established in Warsaw in 1786].

${ }^{3}$ Materials included in the so-called Buczek Catalogue. Scans are available in the Institute of History of the Polish Academy of Sciences in Warsaw.
}

However, the limitations of the method have been acknowledged, with researchers emphasising the uncertain nature of the result data (H. Rutkowski 1973; A. Janeczek 2013; O. Karsvall 2013; T. Związek 2017; B. Szady 2018).

When this method is used to reconstruct the layout of the transport network from the second half of the 18th century on the basis of data from the beginning of the 19th century, there is a temptation to uncritically transfer road connections from the old map. Still, the retrogression's drawbacks suggest that caution should be exercised also for analyses involving periods which are closer to the dates for which cartometric cartographic sources already exist.

The method of recording the geometry of historical roads in the research process constitutes an important problem. It is a consequence of the above-mentioned lack of cartometric maps from the analysed period. T. Panecki (2015, 2018) suggests that the issue could be solved by using so-called retrogressive topology, which is based on the idea of harmonization of historical road lines with the geometry of the cartometric map or BDOT10K 4 .

Reconstruction of the transport network on the basis of cartographic sources requires using a cartographic research method that allows for description and analysis of maps, and, consequently, for the scientific understanding of phenomena (L. Ratajski 1989; J. Pasławski 2010). The research process includes such elements as a direct analysis of selected maps by means of joint analyses of cartographic sources representing various periods and scales (J. Kuna 2018).

Reconstruction of the transport network requires assigning of its various hierarchy elements. It requires application of quantitative methods used for studying socio-economic phenomena, including the statistical method, which makes it possible to, e.g. describe phenomena and determine the degree of their interdependence. For instance, application of the Pearson's correlation coefficient allows to determine the degree of correlation between various phenomena (A. Stanisz 2006), e.g. correlation between settlements and the density of the road network.

\footnotetext{
${ }^{4}$ Database of Topographic Objects (DBTO) which is as detailed as a 1:10,000 topographic map.
} 


\section{Selection of the cartographic reference source}

The oldest particular topographic maps are the starting point for retrogressive research including methods employed by natural sciences, as well as archaeological research and written historical sources (B. Szady 2018). The materials used for reconstruction of the road geometry and identification of the location of elements of the cultural landscape for the Old Poland era are cartographic sources from the 19th and 20th centuries. The map chosen as the base map for the reconstruction of the transport network has to be a source which is in the smallest possible way affected by the 19th-century changes of the road system. According to T. Związek (2017), the road system remained relatively stable and inertial, compared to the previous centuries, until the end of the 18th century. The beginning of the 19th century brought with it the progressive industrialization of Central Europe which caused noticeable changes in the cartographic image recorded on the maps from that period (fig. 1) (Z. Budzyński 2013).

The assessment of the retrogressive potential of selected cartographic sources was carried out using the comparative visual analysis method. Four historic maps were compared and confronted to reconstruct the transport network of the Lublin Voivodship: hereinafter: the Special Map of the Lublin Voivodship of C. Perthées, Heldensfeld's map of Western Galicia, the Quartermaster's Map, and the MGI Tactical Map. Despite their different scales, the maps depict the courses of main roads, making it possible to capture any changes in their layout (fig. 2).

The analyses revealed that the layout of the road network presented on the Heldensfeld's map of Western Galicia is in its most general form consistent with the road system depicted on the Special Map of the Lublin Voivodship of C. Perthées. This map is chronologically closest to the analysed period and does not present significant changes in the road system, unlike the Quartermaster's Map (P. Cebrykow 2015).

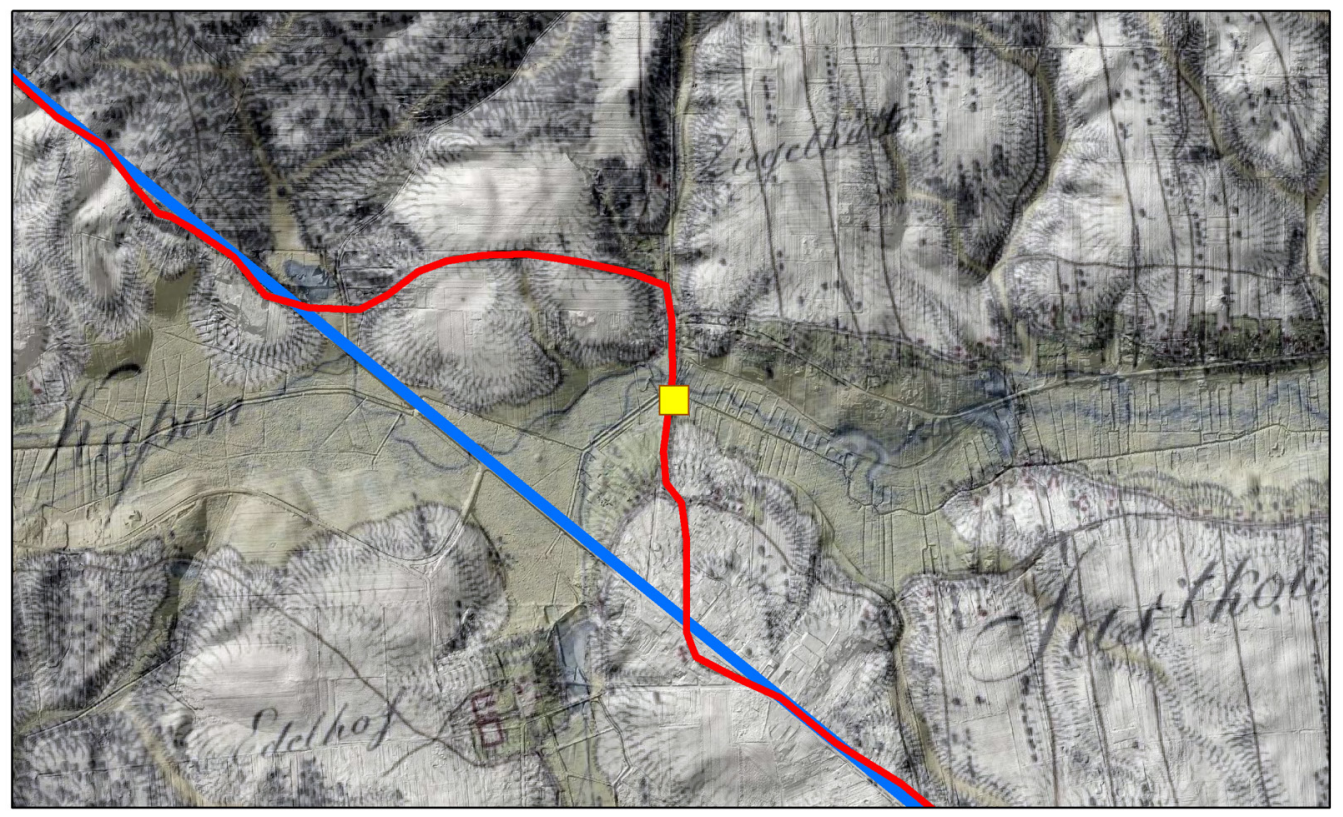

$0 \quad 0,25 \quad 0,5$ $1 \mathrm{~km}$ bridge

Fig. 1. The course of the road through the Ciemięga Valley west of Jastków in the second half of the 18th century - red line; in the first half of the 19th century - blue line (author's own work) 

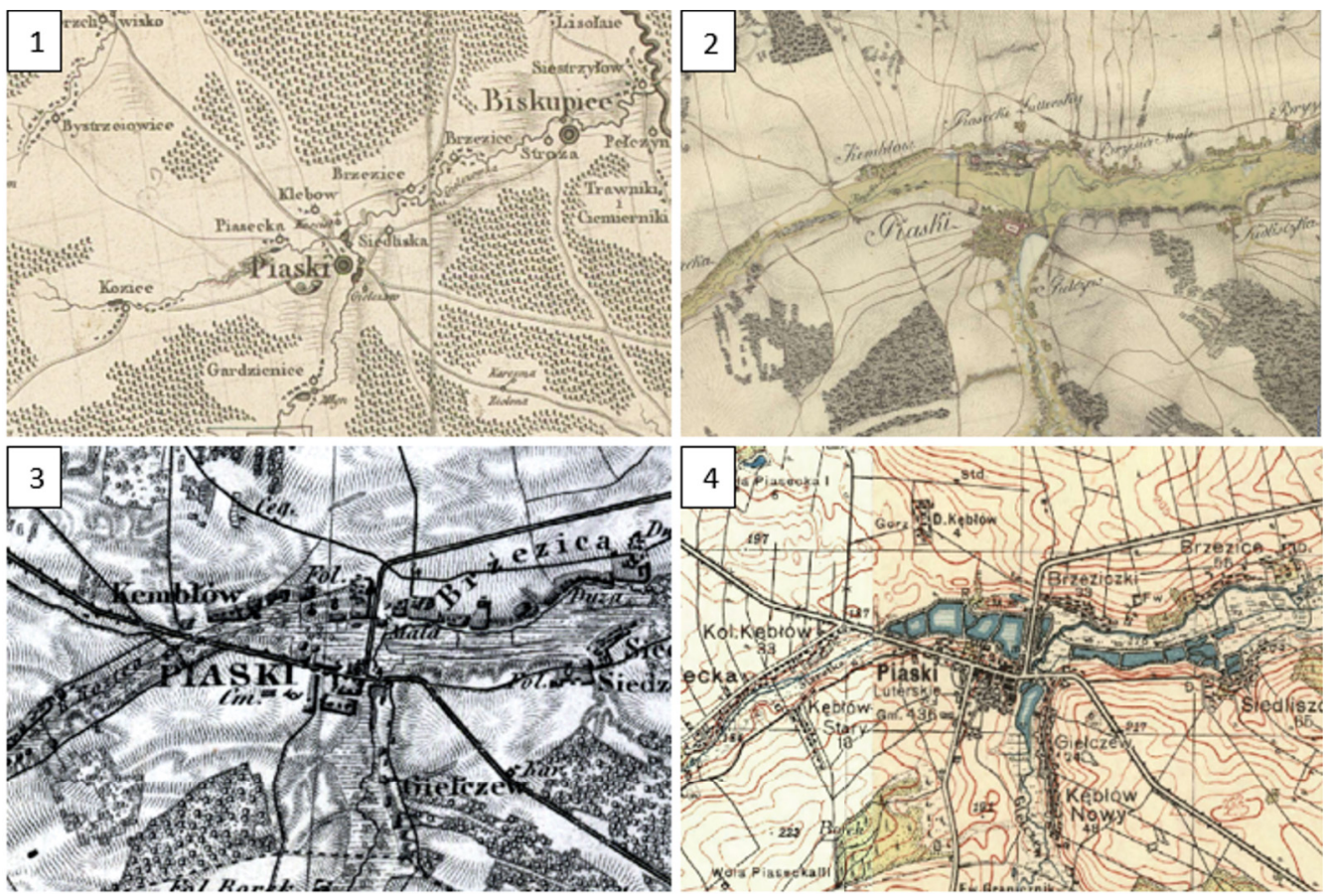

Fig. 2. The road network around Piaski: 1 - a part of the Special Map of the Lublin Voivodship of C. Perthées (1:225,000, 1786), 2 - a part of the Heldensfeld's Map of Western Galicia (1:28,800, 1801-1804),

3 - a part of the Quartermaster's Map (1:126,000, 1843), 4 - a part of the MGI Tactical Map (1:100,000, 1938) (the author's own work)

Subsequent changes noted on the Quartermaster's Map result from the demarcation of improved roads, which replaced older routes, which was confirmed by visual comparative analyses (fig. 3).

\section{Registration of source information}

The use of the GIS environment to develop databases with spatial reference made it possible to standardise information taken from different types of sources and achieve a common denominator, i.e. spatial relations in a measurable reference system (Z. Kozieł 1997; M. Kunz 2006; I. Gregory, P. Ell 2007; B Szady 2008; J. Nita, U. Myga-Piątek 2012; H. Southall 2016; J. Kuna 2018). Standardization of data was carried out in a manner which incorporated the concept of the meta-object proposed by $\mathrm{T}$. Panecki $(2015,2018)$. The existence of objects was verified on the basis of the 18th-century descriptive sources. The locations and courses of individual roads and waterways, i.e. the elements of the transport network, were determined on the basis of later cartographic sources.

The process of recreating the image of the transport network began with the registration of selected elements of the cultural landscape. Depending on the cartometric nature of individual maps, the analysis was conducted with the help of one of the following two approaches which identified the map as either 1) a source of information on the existence of an anthropogenic element or 2) as a source of information about the existence of an anthropogenic element and the location, course and shape of the object.

The first approach was adopted in the analysis of the Special Map of the Lublin Voivodship of C. Perthées, which allowed for initial identification of navigable rivers and road connections between settlement units. What is more, the map was also used to catalogue such selected elements of the transport infrastructure as mills, 


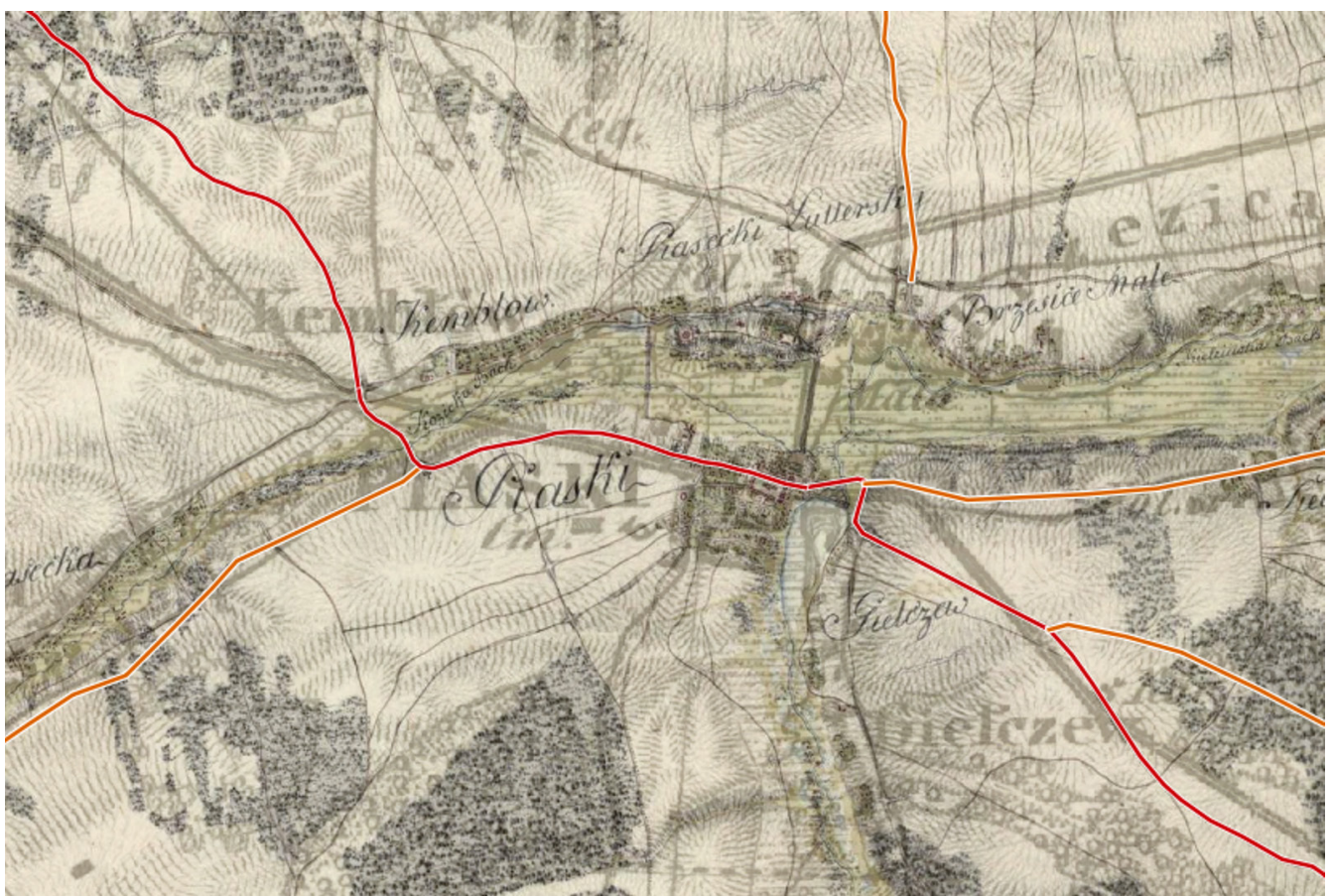

Fig. 3. Comparison of the road network layouts achieved by imposing Heldensfeld's Map of Western Galicia $(1: 28,800,1801-1804)(60 \%$ transparency) on the Quartermaster's Map (1:126,000, 1843): (linear presentation of the geometry of the Western Galicia map's roads - red line: postal roads orange line: high roads) (author's own study)

taverns, customs houses, causeways and postal service stations.

The Heldensfeld's Map of Western Galicia and the Quartermaster's Map were used retrogressively to determine road geometry and verify or reproduce the image of selected elements of the historic anthropogenic landscape. The same sources were used to supplement information on waterways and recreate or identify more closely the location of such cultural landscape objects, as taverns, mills, bridges, transfers, causeways, and customs houses. The courses of selected navigable roads and rivers were verified with the help of the MGI Tactical Map.

\section{Harmonization of source information into critically verified information}

Reconstruction of the transport network required a well-organised research process, which was ultimately divided into five cyclical steps (fig. 4):

1) preliminary identification of the object,

2) verification of the existence of object,

3 ) determination of geometrical parameters of object,

4) verification of object's geometrical parameters of object,

5) validation in the database.

In the first step, the Special Map of the Lublin Voivodship of C. Perthées was used to perform the preliminary identification of the main road connections (high roads and postal roads) between settlement units and the location of transport facilities. As the map contains imprecise representation of the geographical landscape elements, its information content was used only to indicate or verify the existence of the analysed part of the landscape. This means that the map was used as a historical source which contained more information on existence 


\section{PROCESS STEPS}

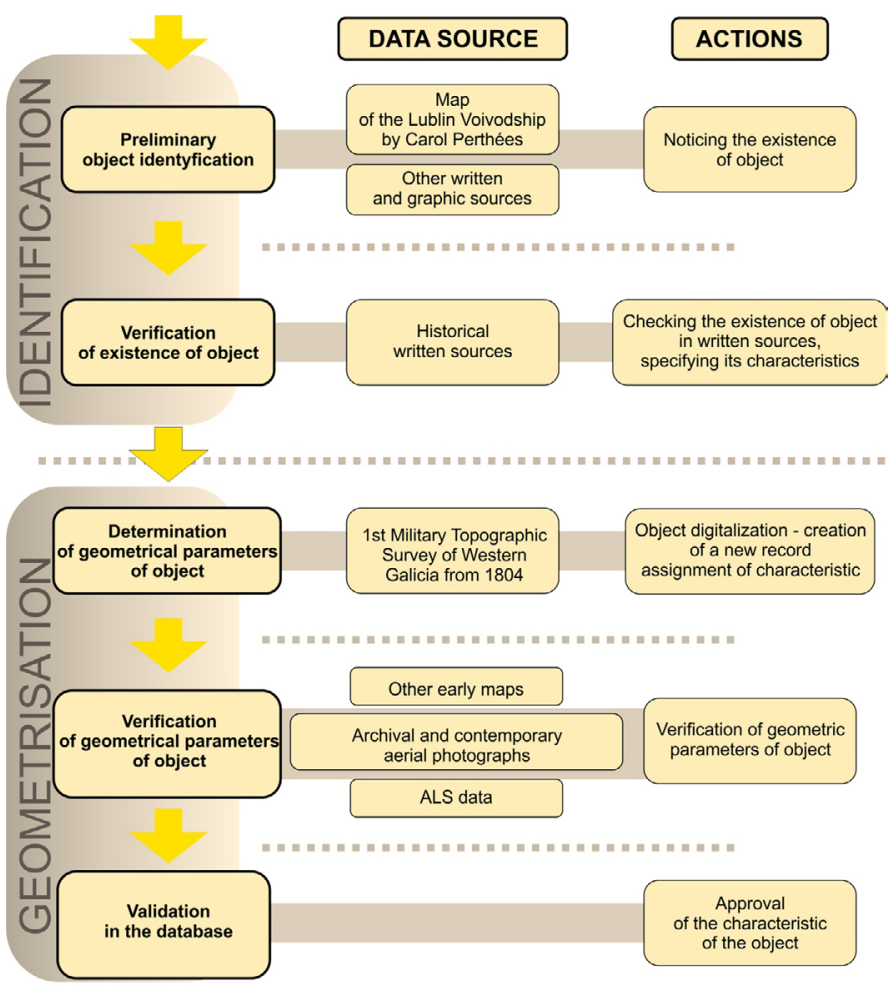

SPATIAL DATABASE

Fig. 4. Diagram of the process of reconstruction of the distribution of elements of the anthropogenic landscape (author's own work)

and features of objects than their topographic locations, shapes or courses 5 .

\footnotetext{
${ }^{5}$ The Special Map of the Lublin Voivodship of C. Perthées was created on the basis of so-called itineraries (Polish: itineraria) (descriptions of roads with information on the distance between settlement units) and the accounts of local people (R. Rutkowski 2014). As a historical source, it has a higher informative than cartographic value (B. Szady 2012b). Identification of road connections on the map should be done with great care, as, according to K. Buczek (1963), the road network shown on the map is "dense, but far from perfect [...], based on the location of localities". H. Rutkowski (2014) noted that the location of almost all localities is in fact inaccurate. B. Szady (2012b) conducted a detailed analysis of the Special Map's content (excluding elements of the geographical environment and the road network) and its cartometric accuracy, which revealed that the map includes numerous
}

Still, the special map of 1796 remains the basic source confirming the existence of transport routes in the Lublin Voivodship in the second half of the 18th century. However, due to its significant inaccuracies, the geometrical parameters of the transport network elements

errors. The most significant inaccuracies relate to the location of localities (which are moved on average 7787 metres to the west). The significant level of inaccuracy of the map does not allow for its direct use in reconstruction of the cultural landscape. This drawback of the map is a result of the method used for its creation. According to K. Buczek (1963), the special maps were the only maps of large areas which were made by a person who had never personally seen the mapped area. 

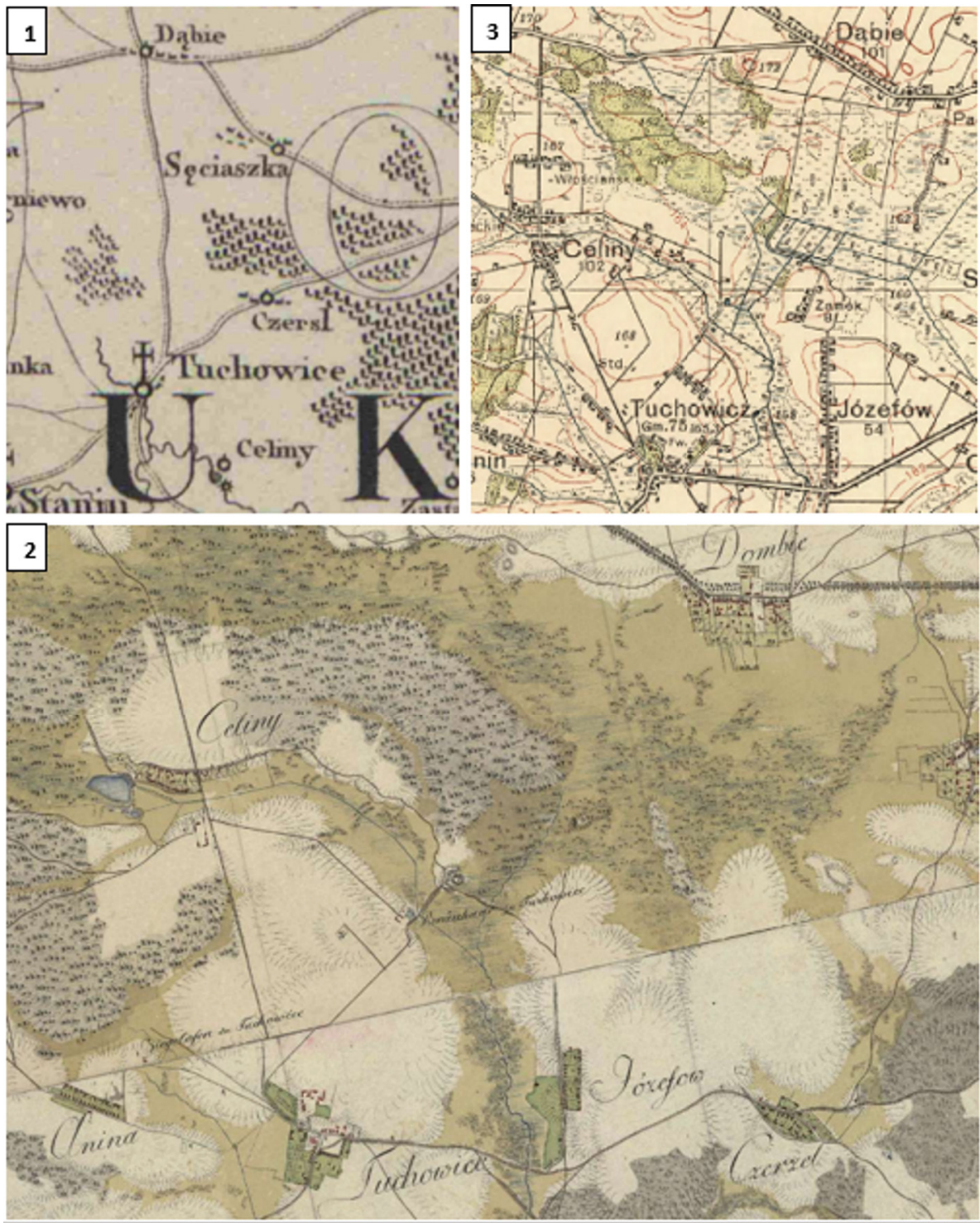

Fig. 5. Differences in the presentation of the road connecting villages Tuchowicz and Dąbie:

1 - a part of the Special Map of the Lublin Voivodship of C. Perthées $(1: 225,000,1786), 2$ - a part of the Heldensfeld's Map of Western Galicia (1:28,800, 1804), 3 - a part of the MGI Tactical Map $(1: 100,000,1938)$ (author's own work)

required verification and further research with the help of sources and materials created in a similar period (mostly later) (fig. 5).

Considering the map's inaccuracies, the next stage of the process consisted of verification of the existence of road connections and their ranks on the basis of descriptive sources. The Geographical and Statistical Description of Parishes was the main reference source for this verification. The information it contained 
was used to confirm whether connections recorded on the map of the Lublin Voivodship really existed. After the verification, information on the way the road was presented in the source was recorded in the database (reference number and information on the label) (fig. 6).

The rank of the road and the detailed course of its sections were verified with the help of other written sources. The Bridge and Causeway Tariff was used to verify the course of the routes. If there were many potential variants of the road connection between any two localities, it was assumed that the variant which included transport facilities (causeways, bridges, and

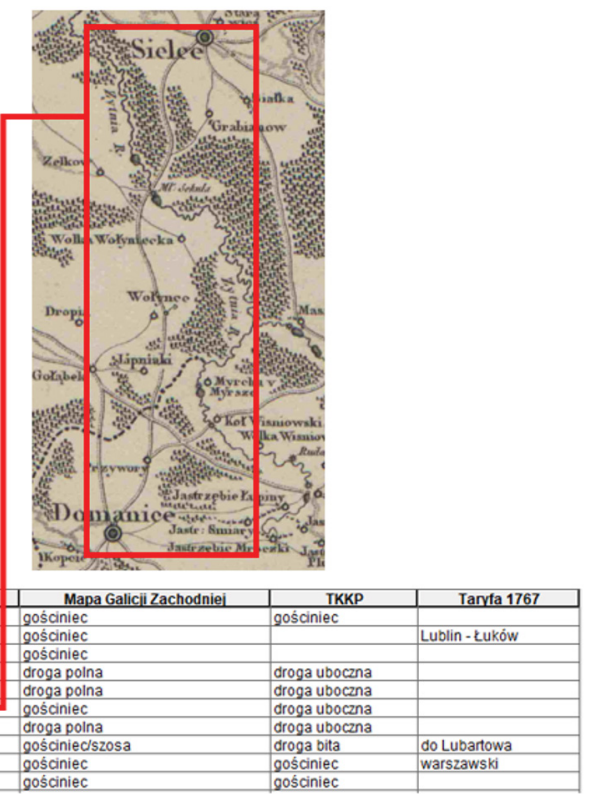

Fig. 6. Recording the attribute information about roads in the attribute table on the example of the Special Map of the Lublin Voivodship of C. Perthées (author's own work)

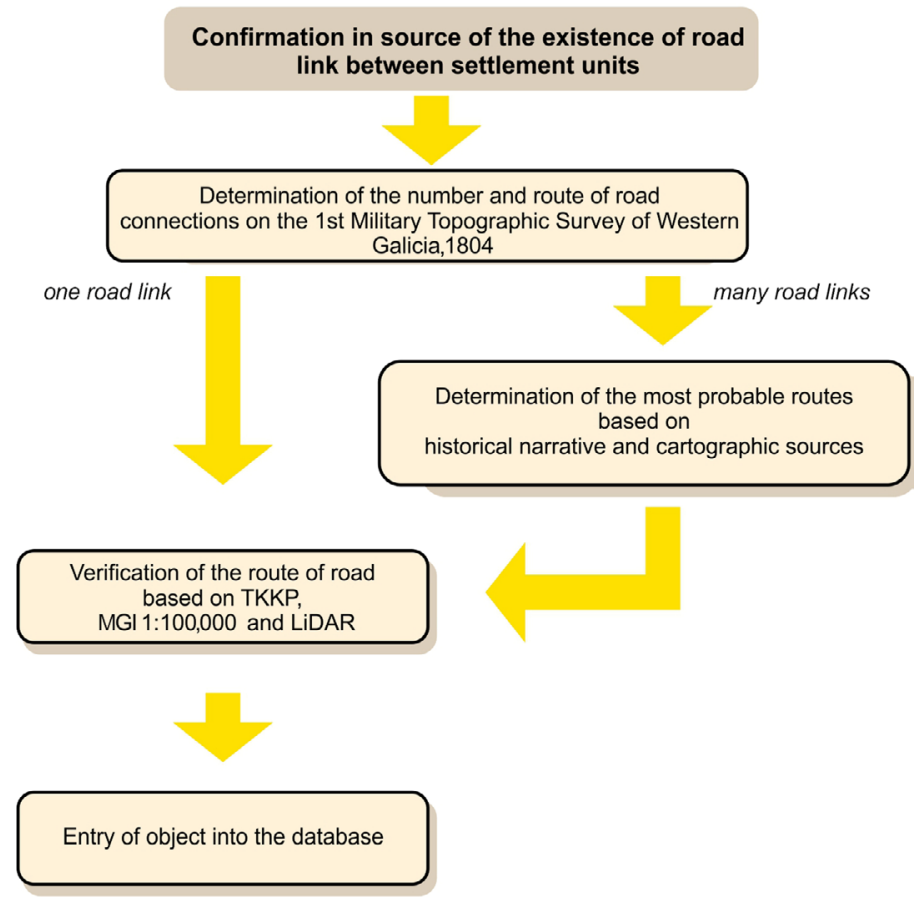

Fig. 7. Diagram of the process of reconstruction of the roads' courses (author's own work) 


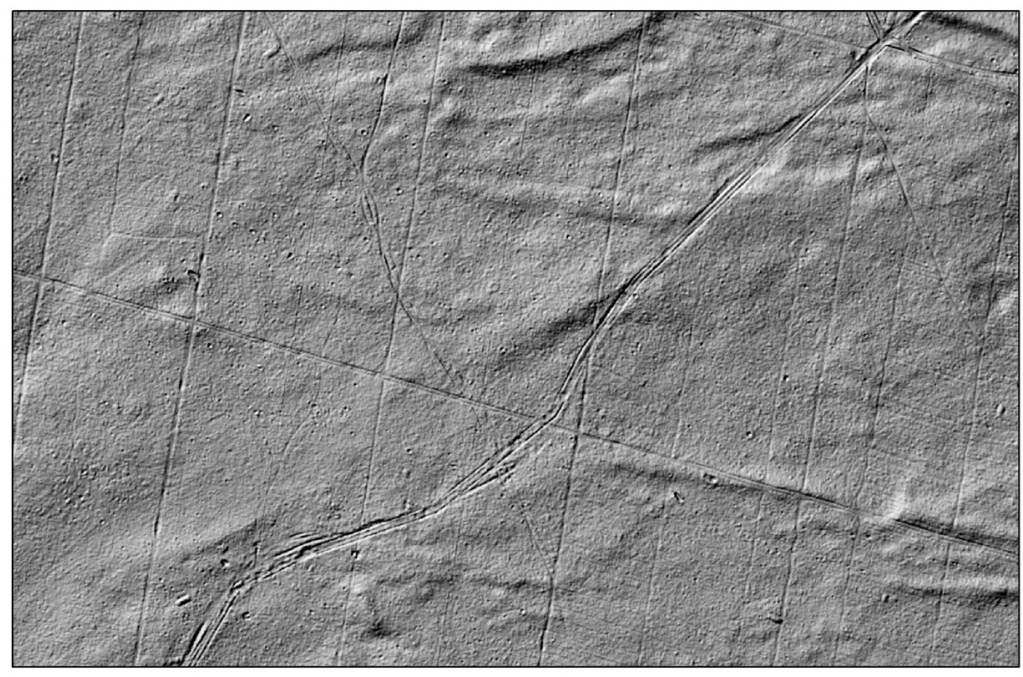

0.125

0.25

$0,5 \mathrm{~km}$

Fig. 8. Preserved terrain form of the no longer existing 18th-century road between Dąbrówka and Nowy Dwór visible on DTM [hillshading] (currently, forest area) (author's own work)

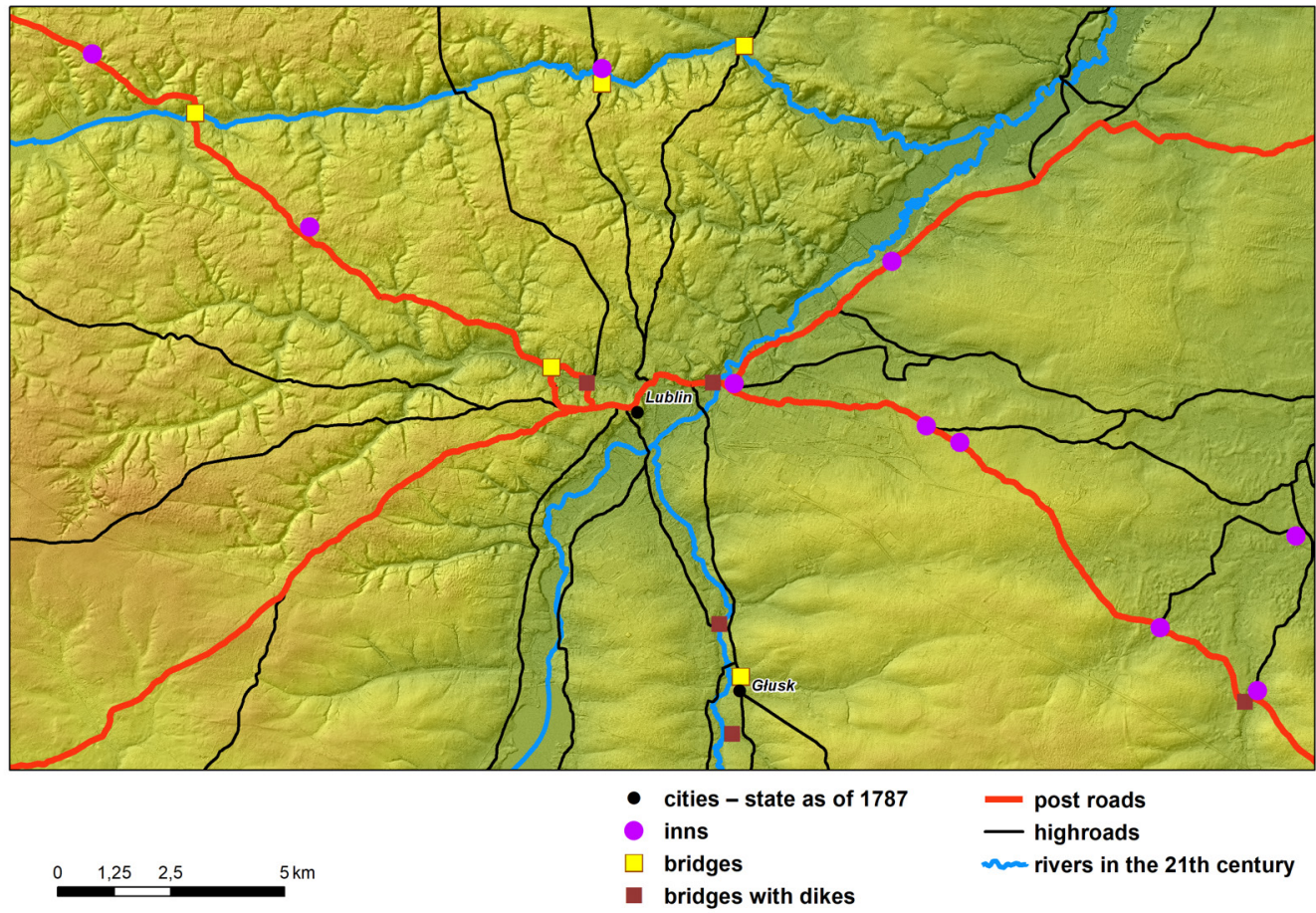

Fig. 9. The layout of the reconstructed transport network in the Lublin area in the second half of the 18th century (author's own work) 
transfers) was the road connection which was actually used in the second half of the 18th century. Furthermore, the Bridge and Causeway Tariff was used to assign the type of road connection to the road geometry, while the course and length of postal roads was verified on the basis of "Dziennik Handlowy".

The road geometry was obtained with the help of selected assumptions of the retrogressive topology method. However, the reverse order of data acquisition was used for the analysis (fig. 7). The input data was the image of the road network based on the Heldensfeld's Map of Western Galicia. The first verified element was the number of road connections between selected localities. If there was only one option of road connection on the map, then the course of the road was verified using later sources: the Quartermaster's Map, and the MGI Tactical Map.

If a road section had the same or very similar course in all sources, a record (of the road section) was added to the spatial database. However, if its course significantly differed between maps, the road geometry was verified on the basis of the Terrain Digital Model. Finally, the verified geometry of the road section was confirmed in the spatial database (fig. 8). If there was more than one possible variant of any road connection, the route was verified with the help of data from descriptive and car-

\section{Literature}

Affek A., 2014, Lotnicze skanowanie laserowe (ALS) w modelowaniu rzeźby terenu - nowe możliwości i pułapki. „Problemy Ekologii Krajobrazu” Vol. 38, pp. 217-236.

Arnold S., 1929, Geografia historyczna, jej zadania i metody. "Przegląd Historyczny" T. 28, no. 1, pp. 91-120.

Banaszek Ł., 2014, Lotniczy skaning laserowy w polskiej archeologii. Czy w pełni wykorzystywany jest potencjał prospekcyjny metody? "Folia Praehistorica Posnaniensia” Vol. 19, pp. 207-251.

Buczek K., 1930, Mapa województwa Krakowskiego z doby sejmu czteroletniego (1788-1792). Źródła i metoda. Kraków: Polska Akademia Umiejętności.

Budzyński Z., 2013, Cesarskie gościńce w Galicji. Pierwszy etap budowy sieci dróg bitych (wg mapy józefińskiej Fryderyka Miega). In: Galicyjskie drogi i bezdroża. Studium infrastruktury, organizacji i kultury podróżowania. Ed. J. Kamińska-Kwak. Rzeszów: Wydawnictwo Uniwersytetu Rzeszowskiego, pp. 25-58.

Cebrykow P., 2015, Dawne mapy topograficzne Lubelszczyzny jako źródła informacji w badaniach tographic sources in order to select the most likely course of the road and carry out the geometry verification process in a manner described in the previous example, ultimately confirming it in the database.

\section{Conclusions}

The methodology and research procedure presented in the article has been used to recreate the layout of the transport network on the basis of diverse sources. The analysis has been based foremost on descriptive and cartographic sources which allowed to accurately reconstruct both the main roads' network of the Lublin Voivodship in the second half of the 18th century (end of the Old Poland period) and the location of various transport facilities (fig. 9). This process required verification and supplementation of information from different type of sources. Adoption of this approach was motivated by the limitations of the available sources, which in the case of maps meant insufficient precision, inconsistencies between representations of the same roads whose courses changed depending on the seasons, and generalisation resulting from the scale of the map (P. Cebrykow 2017). The use of GIS tools made it possible to compare diverse sources and develop a method for their verification.

historyczno-geograficznych (Early topographical maps of Lublin region as information sources in historical-geographical studies). In: Dawne mapy topograficzne w badaniach geograficzno-historycznych (Early topographical maps in geographical-historical studies). Ed. A. Czerny. Lublin: Wydawnictwo UMCS, pp. 85-102.

Cebrykow P., 2017, Cartographic generalization yesterday and today. "Polish Cartographical Review" Vol. 49, no. 1, pp. 5-15.

Denecke D., 1979, Methodische Untersuchungen zur historisch-geographischen Wegeforschung im Raum zwischen Solling und Harz. Ein Beitrag zur Rekonstruktion der mittelaalterlichen Kulturlandschaft. Göttingen.

Gregory, lan; Ell, Paul S., 2007, Historical GIS. Technologies, methodologies and scholarship. Cambridge: Cambridge University Press.

Janeczek A., 2013, Staropolski układ komunikacyjny na mapie józefińskiej Galicji z lat 1779-1783. Szansa czy iluzja rekonstrukcji. In: Galicyjskie drogi i bez- 
droża. Studium infrastruktury, organizacji i kultury podróżowania. Ed. J. Kamińska-Kwak. Rzeszów: Wydawnictwo Uniwersytetu Rzeszowskiego, pp. 9-24.

Karsvall O., 2013, Retrogressiv metod. En översikt med exempel från historisk geografi och agrarhistoria. "Historisk Tidskrift" Vol. 133, no. 3, pp. 411-435.

Kowalczyk R., 2004, Rozwój sieci dróg kołowych w Królestwie Polskim w latach 1815-1918, "Przegląd Nauk Historycznych" T. 3, nr 1, pp. 63-85.

Kozieł Z., 1997, Concerning the need for development of the geomatic research method. "Geodezja i Kartografia" T. 66, nr 3, pp. 217-224.

Kuna J., 2018, Bychawa 1919-1939. Kartograficzna rekonstrukcja miasta. Lublin: Wydawnictwo Uniwersytetu Marii Curie-Skłodowskiej.

Kunz M., 2006, Standaryzacja danych kartograficznych i teledetekcyjnych do analizy zmian struktury krajobrazu. "Roczniki Geomatyki" T. 4, z. 3, pp. 119-129.

Myga-Piątek U., 2005, Historia, metody i źródła badań krajobrazu kulturowego. "Problemy Ekologii Krajobrazu” T. 17, pp. 71-77.

Nieścioruk K., 2004, Z metodyki badania map dawnych. "Annales UMCS” Vol. LIX, Sec. B, pp. 273-281.

Nita J., Myga-Piątek U., 2012, Rola GIS w ocenie historycznych opracowań kartograficznych na przykładzie Wyżyny Częstochowskiej. „Prace Komisji Krajobrazu Kulturowego” No 16, pp. 121-141.

Panecki T, 2015, Modelowanie obiektów topograficznych w bazach danych historycznych. "Acta Universitatis Lodziensis. Folia Geographica Socio-oeconomica" Vol. 21, pp. 37-51.

Panecki T., 2018, Koncepcja struktury bazy danych historycznych obiektów topograficznych. Doctor diss. University of Warsaw, Faculty of Geography and Regional Studies. Warszawa.

Pasławski J. (ed.), 2010, Wprowadzenie do kartografii i topografii. Wrocław: Wydawnictwo Nowa Era.

Plit J., 2014, Analizy geograficzne i historyczne dawnych map. In: Dawne mapy jako źródła w badaniach geograficznych i historycznych. "Z Dziejów Kartografii" T. 18. Warszawa: Instytut Historii Nauki PAN, pp. 19-34.

Ratajczak W., 1999, Modelowanie sieci transportowych. Poznań: Wydawnictwo Uniwersytetu im. Adama Mickiewicza.

Ratajski L., 1989, Metodyka kartografii społeczno-gospodarczej. Warszawa: PPWK.

Rutkowski H., 1973, Drogi. In: Atlas historyczny Polski. Mazowsze w drugiej połowie XVI wieku. Ed. W. Pałucki. Warszawa: Polska Akademia Nauk, pp. 112-120.

Rutkowski H., 1993, Drogi. In: Atlas historyczny Polski. Województwo sandomierskie w drugiej połowie XVI wieku. Ed. W. Pałucki. Warszawa: Polska Akademia Nauk, pp. 121-127.

Rutkowski H., 2014, Fundamenta historiæ. Pisma wybrane. Eds. M. Zbieranowski, M. Słoń. Warszawa:
Instytut Historii PAN, Polskie Towarzystwo Historyczne, Towarzystwo Miłośników Historii.

Semkowicz W., 1925, O potrzebie i metodzie badań nad krajobrazem pierwotnym. In: Pamiętnik Czwartego Powszechnego Zjazdu Historyków Polskich w Poznaniu 6-8 grudnia 1925: I. Referaty. Lwów.

Siemianowska E., 2012, O drogach, szlakach, babach, Prusach i metodzie czyli na marginesie polemiki między Mateuszem Boguckim a Robertem Klimkiem. "Pruthenia. Pismo poświęcone Prusom i ludom bałtyjskim" T. 7, pp. 221-309.

Southall H., 2016, Constructing a Vision of Britain through Time: Integrating old maps, census reports, travel writing, and much else, into an online historical atlas. In: Historical Atlas: Its concepts and methodologies. Northeast Asian Historical Foundation. Ed. P.K. Bol, Seul, pp. 133-151.

Stanisz A., 2006, Przystępny kurs statystyki z zastosowaniem STATISTICA PL na przykładach z medycyny. Warszawa: StatSoft Polska.

Szady B., 2008, Zastosowanie systemów informacji geograficznej w geografii historycznej. "Polski Przegląd Kartograficzny" T. 40, nr 3, pp. 279-283.

Szady B., 2012a, Czasowo-przestrzenne bazy danych jako narzędzie w geografii historycznej. "Acta Universitatis Lodziensis. Folia Geographica Socio-oeconomica" T. 13, pp. 17-32.

Szady B., 2012b, Mapa województwa lubelskiego Karola Perthéesa z 1786 roku jako źródło kartograficzne i historyczne. "Polski Przegląd Kartograficzny" T. 44, nr 3, pp. 26-35.

Szady B., 2018, Dawna mapa jako źródło w badaniach geograficzno-historycznych w Polsce. "Kwartalnik Historii Kultury Materialnej” T. 66, nr 2, pp. 121-141.

Szilágyi M., 2014, On the Road: The history and archaeology of medieval communication networks in East-Central Europe. Budapest: Archaeolingua Alapítvány.

Tyszkiewicz J., 2014, Geografia historyczna. Zarys problematyki. Warszawa: Wydawnictwo DiG.

Wąsowiczówna T., 1953, W sprawie metody badań przebiegu wczesnośredniowiecznych dróg lądowych Polski. "Przegląd Zachodni" T. 9, nr 9-10, pp. 310-320.

Wąsowiczówna T., 1959, Research on the mediaeval road system in Poland. "Archaeologia Polona" Vol. 2, pp. 125-140.

Wąsowiczówna T., 1964, Uwagi w sprawie badań nad siecią drożną wczesnośredniowiecznej Małopolski. In: III Konferencja naukowa w Warszawie 13 i 14 kwietnia 1962. Referaty i dyskusje. Eds. W. Antoniewicz, P. Biegański. Warszawa, pp. 57-66.

Zawadzki M., 2018, Sources and methods of reconstruction of postal roads in the second half of the 18th century on the example of the former Lublin Voivodeship. "Polish Cartographical Review" Vol. 50, no. 4, pp. 197-206. 
Związek T., 2017, Drogi. In: Atlas historyczny Polski. Mapy szczegółowe XVI wieku. Wielkopolska w II połowie XVI wieku. Eds. K. Chłapowski, M. Słoń. Warszawa: Instytut Historii PAN, pp. 268-290.

\section{Cartographic sources}

Mappa szczegulna województwa lubelskiego, 1:225,000, 1786, Karol Perthées, printed 1806, Paris.

Mapa Galicji Zachodniej (Carte von West-Gallizien), 1:28,800, 1801-1804, Anton Mayer von Heldensfeld, manuscript in Wien.

Topograficzna Karta Królestwa Polskiego, 1:126,000, 1822-1843, Karol Richter, Warszawa.

Mapa topograficzna, 1:100,000, 1937-1938, Wojskowy Instytut Geograficzny, Warszawa.

\section{Textual sources - hand-written and printed}

„Dziennik Handlowy, zawierający w sobie wszystkie okoliczności czyli ogniwa całego łańcucha handlu polskiego Zaczęty w Warszawie roku 1786". Available online at: http://pbc.biaman.pl/dlibra/docmetadata?id=35\&from=publication

Kartoteka województwa lubelskiego, Pracownia Atlasu Historycznego Polski, Instytut Historii PAN: Taryfa dymów i podymnego do exakcji lubelskiej wnoszonego z woj. lubelskiego i ziemi łukowskiej, 1775; Tabela dymów w województwie lubelskim, powiat Urzędowski, 1777; Spis Poniatowskiego z 1787 roku; Tabela dymów powiatu urzędowskiego, 1789; Lustracja starostwa ziemi łukowskiej i lustracja starostwa urzędowskiego i gołębskiego, 1789; Taryfa podymnego z dóbr w ziemi lubelskiej położonych r. 1789 ułożona, 1789; Tabela Dymów Ziemi Lubelskiej y Powiatu Urzędowskiego w 1790 r. opisana, 1790; Tabela Dymów Ziemi Lubelskiej y Powiatu Urzędowskiego w 1794 r. opisana, 1794.

Geograficzno-statystyczne opisanie parafiów Królestwa Polskiego w roku 1796 przez K. Perthéesa Geografa Króla Stanisława Augusta. Manuscript at the V. Vernadsky National Library of Ukraine in Kiev (ref. no. I 5975).

Góralski Z., 1956, Taryfa mostowego i grobelnego województwa lubelskiego z 1767 r. "Kwartalnik Historii Kultury Materialnej” nr 3/4, pp. 541-574. 